\title{
Environmental Constraints in Selecting Urban Trees: Landscape Architect' Views
}

\author{
Ramly Hasan, Noriah Othman, Faridah Ismail
}

Faculty of Architecture, Planning and Surveying, Universiti Teknologi MARA,40450 Shah Alam, Selangor, Malaysia ramlyhasan80@yahoo.com, noriaho@yahoo.com, farid346@salam.uitm.edu.my

\begin{abstract}
This research explored the environmental constraints based on landscape architect's views in selecting urban trees. Two objectives have been formulated (i) to examine the practice in selecting tree species among landscape architects and (ii) to determine the relationship between practice and environmental constraints in selecting urban tree species. The findings showed that specific criteria of the environmental constraints are positively correlated and have a strong relationship with tree selection practice. The views of the landscape architect are pertinent in tree selection practice. The findings of this research will contribute to practise improvement in selecting urban tree species by landscape architects in the future.
\end{abstract}

Keywords: environmental; constraints; urban trees; landscape architect

eISSN 2514-751X @ 2019. The Authors. Published for AMER ABRA CE-Bs by e-International Publishing House, Ltd., UK. This is an open-access article under the CC BY-NC-ND license (http:///creativecommons.org/licenses/bync-nd/4.0). Peer-review under responsibility of AMER (Association of Malaysian Environment-Behaviour Researchers), ABRA (Association of Behavioural Researchers on Asians) and CE-Bs (Centre for EnvironmentBehaviour Studies), Faculty of Architecture, Planning \& Surveying, Universiti Teknologi MARA, Malaysia.

https://doi.org/10.21834/aje-bs.v4i12.337 


\subsection{Introduction}

Urban trees are living organism and vital elements of a city's infrastructure should be considered at every stage of planning design and development. In order to properly design for a tree, it is essential to understand the value that urban trees can provide for any project. Benefits of urban trees are continuously discussed in previous research in term of environmental, social, economic, health, aesthetics benefits (Ramly et al., 2017; Vogt, 2017; Kondo ,2017; Salmond ,2016; Mullaney, 2015; Roy, 2012; Kadir, 2012; Chen and Jim, 2008; Buckelew et al, 2007; Nowak et al., 2006). All the benefits are contributed to creating urban fabric and improve the quality of urban lifestyles. However, many professional practices lack the basic knowledge that underlies the science and art of incorporating trees into the urban fabric (Arnold, 1980). Certain urban design and public works standards show that little is known about the basic needs of trees and the selecting of the tree planting. This lack of understanding is a major contributing factor to trees not surviving. According to Moll (1989), the average street tree lives seven to ten years and provides a negative return on investment. Also, space constraints in cities mean that there are only limited opportunities for increasing tree density within existing urban fabric and it is unclear whether the net effect of increased vegetation in street canyons is beneficial or detrimental to urban air quality at local scales ( $\mathrm{Ng}$ et al., 2015).

In Malaysia contexts, urban tree management was managed by the local authority. Landscape architects authorized to selecting the tree species for urban planting. In addition, a person in the top level of management also has the authority to make the decision making in selecting the tree species. However, the deficient in term of knowledge and expertise in the practice of selecting right tree species cause the hazards to the public and properties (Amat, 2011). In addition, due to faults in selecting tree species, many things will happen such as pavement damage was fallen trees, increase the tree maintenances and blocking the windshield (Ramly et al., 2017). Because of that, the aim of this study is to ensure the selection of trees species is appropriate to the place and conditions. To achieve the aim, two objectives have been formulated, (i) to examine the practice on selecting tree species among landscape architect and (ii) to determine the relationship between practice and environmental constraints in selecting urban tree species.

\subsection{Literature Review}

\subsection{Factors of Urban Tree Growth}

Some authors have been carried out to understand and explore the possible value of genetic control of plants for agriculture improvement and landscape design (Myralyn et al., 2014; Antoine et al., 2011 and Alejandro et al., 2008). Environmental factors are considered significant control mechanism for urban tree growth. Factors such as water, extreme temperature and wind, poor soil condition, nutrient content and related factors that influence physiological processes such as photosynthesis and respiration all contributions are great to 
the growth of urban tree needs (Han et al., 2008 and Antony, 2000). According to James (2014), there are three aspects of tree growth and development that are associated with a time; juvenility and maturity, existing structure and ageing. In the plant's community, several classes' chemicals have been separated and Identified. These chemicals are referred as plant growth regulators or hormones reputed to plant development control (George, 2012).

Table 1: Factors of Tree Growth

\begin{tabular}{|l|l|}
\hline Factors & Items \\
\hline Genetic controls & $\begin{array}{l}\text { Pets and environmental tolerance, tree life story, tree lifespan, } \\
\text { compartmentalization response and production of allopathic chemical }\end{array}$ \\
\hline Environmental control & $\begin{array}{l}\text { Water, sunlight, wind, moisture, temperature, soil condition and nutrient } \\
\text { content }\end{array}$ \\
\hline Time & Maturity period \\
\hline Plant growth regulations & Auxin, Cytokine, abscisic acid, gibberellins and ethylene \\
\hline
\end{tabular}

(Source: Jasasikin, 2015)

\subsection{Environmental constraints in Selecting Urban Tree Species}

The term environmental is used here to describe tree selection criteria that relate to the interactions of the tree with its physical surrounding. Environmental criteria were mainly expressed in the literature as environmental constraints or environmental limitations which confine the list of appropriate tree species (Zanetti et al., 2015; Sabo et al., 2005; Sabo et al., 2003; Appleton, 2000; Miller, 1997). Trees and other plants have found many different ways to adapt to stressful environments including urban environments. These adaptations were not further specified here but listed according to the environmental constraint. For example, different tree species may show different ways of dealing with air pollution. Also, tolerance or adaptation to urban infrastructure and structure differs between tree species.

Several publications in arboricultural research have presented potential solutions to some of the above limitations, especially for street tree plantings. An example is the use of tree root barriers to prevent curb lifting (Morgenroth, 2008; Smiley, 2008). Miller (1997), for example, referred to diversity and stability of the tree population, addressing species diversity and tree age diversity. Tree species diversity was emphasized by several authors (Ramesha et al., 2017; Dawud et al., 2016; Nguyen et al., 2016; Pedro et al., 2015) especially in regards to the spread of pests and diseases. Naderali et al., (2015), for example, described of Roystonea regia (Royal palm) due to Yellow Decline Disease (Phytoplasma (16Srl)) subsequently prompted attention about the risk of monoculture tree plantings and also tree plantings that are dominated by only few tree species. Miller (1997), too, warned that using cultivars of only three or four tree species may not be in the interest of species diversity. However, to overcome monoculture or strongly dominated tree plantings, Miller (1997) suggested changing tree species either by street or by block. In his opinion, this would comply with the desired uniformity in street design and maintenance efficiency. As an alternative, Miller (1997) proposed to select tree species with similar appearance and similar physiological requirements. Four important criteria in environmental constraint are listed which are climatic, Edaphic, physiographic and biologic. All these criteria are tested with the 
process influencing on selecting tree species in an urban area.

\subsection{Methodology}

This research used a mixed method approach which based on the analysis of qualitative and quantitative data collection. The purpose of the qualitative approach is for in-depth interviews conducted with a senior landscape architect in the local authority. Secondly, are using literature reviews. A critical literature review was conducted on theories related to tree species selection and factors are influencing in selecting tree species were studied. For quantitative approach researchers used questionnaire survey and analyzed in SPSS software to test the relationship between process considerations and factors affecting in selecting tree species. Because of data are non- parametric, Kendall tau-b is used to test the correlations. For the quantitative approach, 375 of the landscape architects were select for answered the questionnaire survey. The method used is descriptive analysis, one way ANOVA and Correlation test. The selections of the respondents for in-depth interview are one senior landscape architect based on experience and knowledgeable in selecting tree species at Kuala Lumpur City Hall, Petaling Jaya City Council, Selayang Municipal Council and Subang Jaya Municipal Council. The selection of local authority is based on their promise to share the information. The main questions were asked 'what is the practise consideration during selecting tree species in urban area? All the important process is described using the coding technique in ATLAS ti software. Figure 1 showed the process of collecting data in this study.

Figure 1. Process of data collection in this research

\begin{tabular}{|c|c|}
\hline $\begin{array}{l}\text { Qualitative approach } \\
\text { In-depth Interview } \\
\text { Interviewees =4 (landscape architects) }\end{array}$ & $\begin{array}{l}\text { Quantitative approach } \\
\text { Questionnaires survey ( } 375 \text { sample) }\end{array}$ \\
\hline$\downarrow$ & $\downarrow$ \\
\hline $\begin{array}{l}\text { Data analysis } \\
\text { Atlas ti. software (using the coding technique) }\end{array}$ & $\begin{array}{l}\text { Data analysis } \\
\text { SPSS software (One way ANOVA \& Correlation) }\end{array}$ \\
\hline
\end{tabular}

\subsection{Results}

\subsection{Interviews Results}

The interviews lasted about an hour to an hour and a half. During the interviews the respondents were asked the same questions set in the same order. The answers were openended and provided opportunities to give their comments of which some were further questioned and considered. The selections of the landscape architects are based on the knowledge and experiences in handling the selection of roadside trees. Two male and two 
female are selected from different authority to see the different view of how the street trees twere selected. Interviewees at City Councils had more than ten years of work experience and interviewees from Municipal Councils had less than ten years' experience. Two City Councils; Kuala Lumpur City Hall and Petaling Jaya City Council and two Municipal Councils; Subang Jaya Municipal Council and Selayang Municipal Council were selected to catch the similarities and differences in selected roadside trees. From the data interviews, researchers were analyzing the data and make it in seven practises of selection tree species. The results are according to the selection process addressed in table 2 . Example of the quote from the respondents such as:

The first code 'framework and plan' was addressed by half the interviewees. The following quote of the respondent describes this code best:

"Due to the increasing number of problem trees occurs in roadside at Kuala Lumpur, we have gone through a process to develop a set of Street Tree Management Plan for long-term management of urban trees".

The codes of 'themes' mentioned by two interviewees. The theme was explained as characteristics of a street. Common themes are based on historical development of street, closeness to building facade and facilities such as Monorail station and construction areas. The theme also reflects the hierarchy of roads in an urban area such as protocol roads, primary roads, secondary roads, highway and main roads.

"..Starting in1990's, mostly in the roadside area is planted with Khaya senegalensis, the trend change planted with flowering trees such as Tabebuia rosea and Pelthoporum ptrerocarpum and next is Terminalia mentaly.. The trending of selection roadside tree nowadays is to maintain the identity of the roads through planted flowering tree and concern on interesting shapes of a tree."

Table 2. Important codes of practise consideration during selecting street tree species

\begin{tabular}{|c|c|}
\hline Code & Explanation \\
\hline Framework and plan & Basic supporting structure or rules in selected roadside tree \\
\hline Trending & Change or develop in selected tree species \\
\hline Landscape policies & $\begin{array}{l}\text { The principle of action by National Landscape Department such as blueprint, } \\
\text { approach and guidelines to propose roadside tree }\end{array}$ \\
\hline Decision maker & A person who can make the decision making \\
\hline Limiting factors & Environmental conditions that limit the roadside tree growth \\
\hline Themes & $\begin{array}{l}\text { Describes the characteristics of a street need a match with suitable trees } \\
\text { species }\end{array}$ \\
\hline Budget constraint & Cost barrier for purchase and maintenance part of roadside trees \\
\hline
\end{tabular}

\subsection{Survey Results}

\subsubsection{Mean comparison between types of organization with environmental constraints in selecting tree species using One -Way ANOVA}

Table 3 shows the mean comparison between criteria of environmental constraints and organization of respondents. There are four criteria of tree selection practise that shows highly significant differences $p<0.01$ which are climatic, edaphic, physiographic and biologic. 
For climatic, the landscape architects in landscape contractors firm rated higher than other organizations. For edaphic, the landscape architects in the government agency, rated the highest but they rated lowest for the biologic factors.

Table 3. Mean Comparison between the type of organization and environmental constraints

\begin{tabular}{|c|c|c|c|c|c|c|}
\hline $\begin{array}{l}\text { Type of } \\
\text { organizations } \\
\text { Criteria }\end{array}$ & $\begin{array}{l}\text { Landscape } \\
\text { consultants } \\
(\mathrm{N}=128)\end{array}$ & $\begin{array}{l}\text { Landscape } \\
\text { developers } \\
(\mathrm{N}=64)\end{array}$ & $\begin{array}{l}\text { Government } \\
\text { agency } \\
(\mathrm{N}=87)\end{array}$ & $\begin{array}{l}\text { Landscape } \\
\text { contractors } \\
(\mathrm{N}=96)\end{array}$ & $\mathrm{F}$ & Sig. \\
\hline Climatic & 4.54 & 4.50 & 4.03 & 4.64 & 15.43 & $0.00^{* *}$ \\
\hline Edaphic & 4.22 & 4.26 & 4.62 & 4.29 & 5.87 & $0.00^{* *}$ \\
\hline Physiographic & 4.52 & 4.30 & 4.54 & 4.04 & 11.31 & $0.00^{* *}$ \\
\hline Biologic & 4.35 & 4.51 & 3.95 & 4.43 & 7.37 & $0.00^{* *}$ \\
\hline \multicolumn{7}{|c|}{$\begin{array}{l}\text { Note: Likert Rating Scale: } 1 \text {-Strongly disagree, 2-Disagree, 3- Moderate, 4-Agree, 5- Strongly agree } \\
{ }^{*} \text { Significant differences at } p<0.05 \\
{ }^{*} \text { Highly significant differences at } p<0.01\end{array}$} \\
\hline
\end{tabular}

\subsubsection{Relationship between environmental constraints against tree selection practise using Correlation Coefficient}

Table 4 elaborated the results of the correlation test using Kendall's tau for environmental constraint against the important practise consideration in selecting tree species. Overall, the values of the correlation coefficient are positive. Criteria for climatic against framework and plan indicates significant different, low correlation and weak relationship (tau $=0.362^{*}, p<0.01$ ) followed by biologic criteria's showed moderate correlation and substantial relationship between framework and plan (tau $=0.589^{* *}, p<0.01$ ). For edaphic criteria's showed the slight correlation and no relationship (tau $=0.095^{* *}, p<0.05$ ). However, no significance difference between physiographic with framework and plan (tau $=0.223, p<0.01$ ). Meanwhile, criteria for biologic against trending showed high correlation and marked relationship (tau $=0.782^{* *}$, $p<0.01$ ). Two negative correlations showed slight correlation and no relationship which are edaphic and physiographic against trending (tau $=-0.060, p<0.05)$ and $(\operatorname{tau}=-0.053, p<0.05$ ). Criteria for climatic showed the moderate correlation and substantial relationship between trending (tau $=0.589^{\star}, p<0.01$ ). Criteria for climatic and biologic against landscape policies showed moderate correlation and substantial relationship (tau $=0.413^{*}, p<0.01$ ) and (tau $=$ $0.513^{* *}, p<0.01$ ). Criteria for edaphic and physiographic showed the slight correlation and no relationship between landscape policies (tau $=0.019, p<0.05)$ and $\left(\operatorname{tau}=0.052^{* *}, p<0.05\right)$. Furthermore, the correlation coefficient values between edaphic and showed substantial relationship, meaning that a moderate correlation likely occurred in the decision maker (tau $\left.=0.467^{* *}, p<0.01\right)$ and (tau $\left.=0.603^{*}, p<0.01\right)$. Criteria for climatic showed the low correlation and weak relationship between decision maker (tau=0.209, $p<0.01$ ) and followed by biologic criteria's showed slight correlation and no relationship between personal preferences (tau $=0.177, p<0.01$ ). Two criteria of environmental constraint showed the low correlation and weak relationship which are climatic and edaphic against limiting factors (tau $\left.=0.310^{* *}, p<0.01\right)$ and (tau $\left.=0.267^{* *}, p<0.01\right)$. Criteria for physiographic showed the high 
correlation and marked the relationship between limiting factors (tau $\left.=0.702^{* *}, p<0.01\right)$. However, no significant difference, slight correlation and no relationship between biologic and limiting factors (tau $=0.099, p<0.05$ ). All criteria of environmental constraints indicate the significance different between themes. Criteria for climatic and physiographic showed the low correlation and weak relationship between themes (tau $=0.377^{*}, p<0.01$ ) and (tau $=0.288^{* *}$, $p<0.01)$.For biologic against themes showed moderate correlation and substantial relationship $\left(0.642^{* *}, p<0.01\right)$ followed by criteria for edaphic against themes showed the slight correlation and no relationship $\left(0.153^{* *}, p<0.01\right)$. Criteria for climatic and physiographic showed the moderate correlation and substantial relationship between budget constraint (tau $\left.=0.617^{*}, p<0.00\right)$ and $\left(\operatorname{tau}=0.538^{* *}, p<0.00\right)$. For biologic against budget, constraint showed low correlation and weak relationship $(0.244, p<0.01)$ followed by criteria for edaphic against budget constraint showed the slight correlation and no relationship $(0.129, p<0.01)$.

Table 4. Kendall tau-b correlation between criteria of environmental constraints and tree selection practise

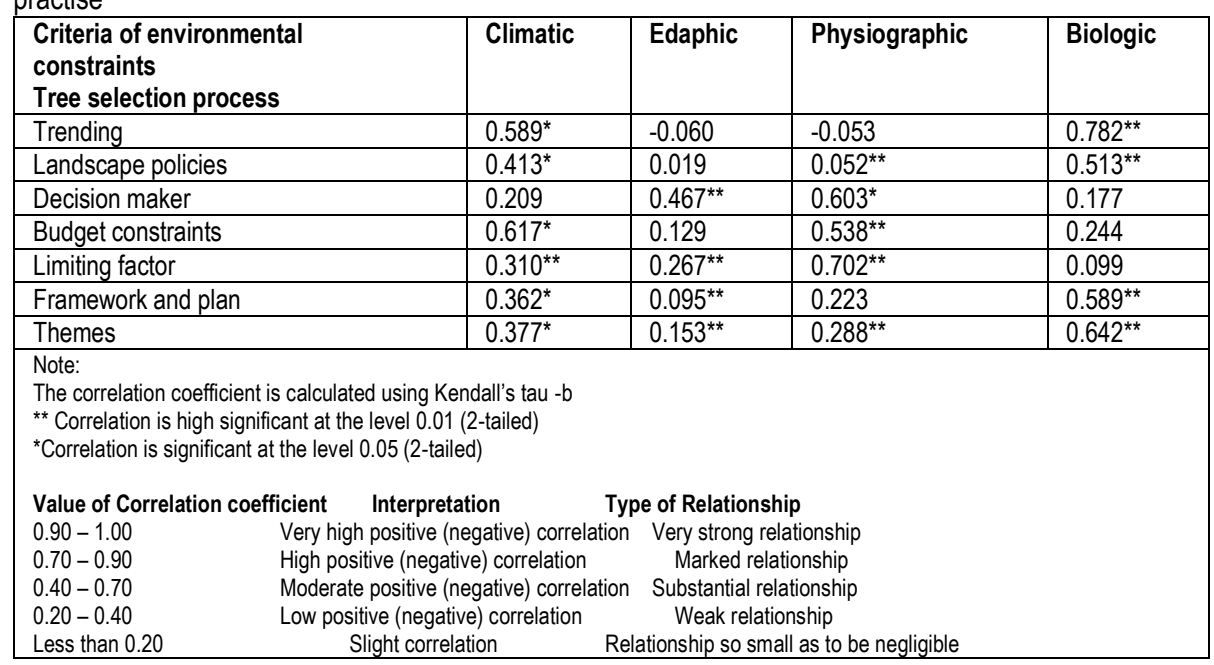

\subsection{Discussions}

The findings for tree selection practices in Malaysia are based on four types of organizations which are landscape consultants, landscape developers, landscape contractors and government agency. Interviews results indicate seven tree species practise are based on trending, landscape policies, decision maker, budget constraints, limiting factors, framework and plan and themes. The landscape architects create the landscape and plan, design and manage the spaces including natural and built environment. Supported by previous research, Sheppard (2015) stated that landscape architects could play an integrative and visionary role in creative design and engagement of communities on climate change. Their work provides 
innovative and aesthetically pleasing environments for people to enjoy while ensuring that changes to the better environment are appropriate, sensitive and sustainable. Overall, the findings of the research will contribute to the knowledge of tree selection practise among landscape architects.

\subsection{Conclusion}

Selecting right tree species in the right place are pertinent part of creating urban area. Selecting optimal and suitable trees in the urban area can minimize the negative influence and increase the positive effects. Landscape architects have been created a healthy environment through appropriate tree selection. The proper tree selection practice is an important part in determining the suitable tree species. Environmental constraints were introduced by Miller Model are helped in determining the relationship with tree selection practice.

\section{Acknowledgements}

The authors would like to extend the utmost appreciation to the respondents for their exceptional dedication and enthusiasm and for sharing their valuable time and support. This appreciation also goes to Geran Insentif Penyeliaan (GIP) (600-IRMI / MyRA 5/3/GIP (025/2017) from Research Management Centre, Universiti Teknologi MARA, Shah Alam, Selangor, Malaysia for the expertise and financial support. The authors also acknowledge the constructive comments for reviewing the manuscript.

\section{References}

Amir, S., \& Misgav, A. (1990). A framework for street tree planning in urban areas in Israel. Landscape and Urban Planning, 19(3), 203-212

Appleton, B. (2000). Right tree - right location. Arborist News, 9, 50-54.

Arnold. H. F. (1980). Trees in Urban Design. New York, New York: Van Nostrand Reinhold Company.

Bassuk, N. (1990). Street tree diversity making better choices for the urban landscape. Paper presented at the 7th Conference of the Metro Tree Improvement Alliance (METRIA), The Morton Arboretum, Lisle, Illinoi

Chen, W. Y., \& Jim, C. Y. (2008). Assessment and valuation of the ecosystem services provided by urban forests. In M. M. Carreiro, J. Wu \& Y.-C. Song (Eds.),Ecology, Planning, and Management of Urban Forests: International Perspectives. New York: Springer.

Dawud, S. M., Raulund-Rasmussen, K., Domisch, T., Finér, L., Jaroszewicz, B., \& Vesterdal, L. (2016). Is tree species diversity or species identity the more important driver of soil carbon stocks, C/N ratio, and pH?. Ecosystems, 19(4), 645-660. 
Gerhold, H. D., \& Porter, W. (2007). Selecting trees for community landscapes. In J. E. Kuser (Ed.), Urban and Community Forestry in the Northeast (2nd ed.): Springer.

Hasan, R., Othman, N., \& Ismail, F. (2017). Tree Species Selection in Street Planting: It's relationship with issues in urban area. Environment-Behaviour Proceedings Journal, 2(6), 185-194.

Hasan, R., Othman, N., \& Ismail, F. (2017). Social Factors Influencing Hazardous Street Trees at Selected City Council in Malaysia. Environment-Behaviour Proceedings Journal, 2(5), 215-222.

Kadir, M. A. A., \& Othman, N. (2012). Towards a better tomorrow: street trees and their values in urban areas. Procedia-Social and Behavioral Sciences, 35, 267-274.

Kirnbauer, M. C., Kenney, W. A., Churchill, C. J., \& Baetz, B. W. (2009). A prototype decision support system for sustainable urban tree planting programs. Urban Forestry \& Urban Greening, 8, 3-19.

Kondo, M. C., Han, S., Donovan, G. H., \& MacDonald, J. M. (2017). The association between urban trees and crime: Evidence from the spread of the emerald ashborer in Cincinnati. Landscape and Urban Planning, 157, 193-199.

Moll, C.W. (1989). The State of Our Urban Forest. American Forests 95, 61-64

Morgenroth, J. (2008). A review of root barrier research. Arboriculture \& Urban Forestry, 34, 84-88.

Mullaney, J., Lucke, T., \& Trueman, S. J. (2015). A review of benefits and challenges in growing street trees in paved urban environments. Landscape and Urban Planning, 134, 157-166.

Ng, W.Y. \& Chau, Chi. K. P., Greg L., Tze-M. (2015). Preferences for street configuration and street tree planting in urban Hong Kong. Urban Forestry \& Urban Greening. 14. 30-38

Naderali, N., Vadamalai, G., Nejat, N., \& Ling, K. L. (2015). First report of phytoplasma (16Srl) associated with yellow decline disease of royal palms [Roystonea regia (Kunth) OF Cook] in Malaysia. Journal of Phytopathology, 163(2), 133-137.

Nguyen, D. T., Cleary, M. R., Enderle, R., Berlin, A., \& Stenlid, J. (2016). Analyses of the ash dieback pathogen, Hymenoscyphus fraxineus, suggest role of tree species diversity on colonization and population structure differentiation. Forest Pathology, 46(1), 82-84.

Nowak, D. J., Hoehn, R., Crane, D. E., Stevens, J. C., \& Walton, J. T. (2006). Assessing urban forest effects and values: Washington, D.C.'s Urban Forest. Northern Research Station: United States Department of Agriculture Forest Service.

Pedro, M. S., Rammer, W., \& Seidl, R. (2015). Tree species diversity mitigates disturbance impacts on the forest carbon cycle. Oecologia, 177(3), 619-630.

Roy, S., Byrne, J., \& Pickering, C. (2012). A systematic quantitative review of urban tree benefits, costs, and assessment methods across cities in different climatic zones. Urban Forestry \& Urban Greening, 11(4), 351-363.

Ramesha, M. N., Dwivedi, V. K., Singh, C., \& Kumar, V. (2017). Incidence of Ganoderma lucidum L.(Reishi) on Delonix regia and Peltophorum pterocarpum in Semi-Arid Region. Indian Forester, 143(2), 139-142.

Sabo, A., Benedikz, T., \& Randrup, T. B. (2003). Selection of trees for urban forestry in the Nordic countries. Urban Forestry and Urban Greening, 2, 101-114

Sabo, A., Borzan, Z., Ducatillion, C., Hatzistathis, A., Lagerström, T., Supuka, J., Garcia- Valdecantos, J. L., Rego, 
F., \& Van Slycken, J. (2005). The selection of plant materials 223for street trees, park trees and urban woodlands. In C. C. Konijnendijk, K. Nilsson, T. B. Randrup \& J. Schipperijn (Eds.), Urban forests and trees: a reference book. Berlin; New York: Springer.

Salmond, J. A., Tadaki, M., Vardoulakis, S., Arbuthnott, K., Coutts, A., Demuzere, M., \& Mclnnes, R. N. (2016). Health and climate related ecosystem services provided by street trees in the urban environment. Environmental Health, 15(1), S36.

Santamour Jr., F. S. (1990). Trees for urban planting: Diversity, uniformity, and common sense. Paper presented at the 7th Conference of the Metro Tree Improvement Alliance (METRIA), The Morton Arboretum, Lisle, Illinoi Sheppard, S. R. (2015). Making climate change visible: A critical role for landscape professionals. Landscape and Urban Planning, 142, 95-105.

Smiley, E. T. (2008). Comparison of methods to reduce sidewalk damage from tree roots. Arboriculture \& Urban Forestry, 34, 179-183

Vogt, J., Gillner, S., Hofmann, M., Tharang, A., Dettmann, S., Gerstenberg, T., \& Roloff, A. (2017). Citree: A database supporting tree selection for urban areas in temperate climate. Landscape and Urban Planning, 157, 1425.

Zanetti, C., Vennetier, M., Mériaux, P., \& Provansal, M. (2015). Plasticity of tree root system structure in contrasting soil materials and environmental conditions. Plant and soil, 387(1-2), 21-35. 